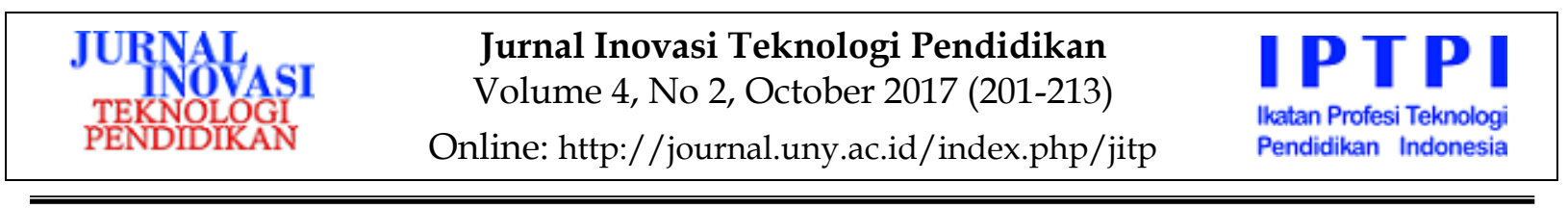

\title{
PENGEMBANGAN MULTIMEDIA PEMBELAJARAN INTERAKTIF IPA UNTUK MENINGKATKAN PEMAHAMAN SISWA PADA MATERI MIKROORGANISME SMP
}

\author{
Hotimah, Ali Muhtadi \\ SMP N 1 Wates, Fakultas Ilmu Pendidikan UNY \\ hotimahkusuma@yahoo.co.id, ali_bintangku@yahoo.co.id
}

\begin{abstract}
Abstrak
Penelitian ini bertujuan: (1) untuk menghasilkan multimedia pembelajaran interaktif IPA pada materi mikroorganisme yang layak di SMP, dan (2) untuk mengetahui kelayakan multimedia pembelajaran interaktif IPA dalam peningkatan pemahaman siswa pada materi mikroorganisme. Penelitian pengembangan ini mengacu pada langkah yang dikembangkan oleh Alessi \& Trollip. Desain pengembangan dikelompokkan menjadi tiga tahapan prosedur pengembangan, yang meliputi: (a) perencanaan, (b) desain, dan (c) pengembangan. Hasil penelitian menunjukkan hasil sebagai berikut. (1) Ahli materi menilai aspek pembelajaran dan aspek materi dengan kategori baik (skala 4,15), ahli media menilai aspek media dengan kategori baik (skala 4,2), dan siswa (pengguna) menilai aspek pembelajaran, aspek materi, dan aspek media dengan kategori sangat baik (skala 4,5), sehingga dapat disimpulkan bahwa produk multimedia pembelajaran interaktif ini dinilai layak digunakan siswa SMP. (2) Hasil uji coba lapangan (hasil pretes dan postes) menunjukkan bahwa multimedia interaktif IPA ini dapat meningkatkan pemahaman siswa pada materi mikroorganisme.

Kata kunci: multimedia pembelajaran interaktif, mikroorganisme
\end{abstract}

\section{DEVELOPING INTERACTIVE MULTIMEDIA TO IMPROVING LEARNERS' UNDERSTANDING ON THE MICROORGANISMS TOPIC IN JUNIOR HIGH SCHOOL}

\author{
Hotimah, Ali Muhtadi \\ SMP N 1 Wates, Fakultas Ilmu Pendidikan UNY \\ hotimahkusuma@yahoo.co.id, ali_bintangku@yahoo.co.id
}

\begin{abstract}
This research aims to: (1) to produce an appropriate interactive learning multimedia of science for teaching on the microorganisms topic, for Junior High School students, and (2) to reveal the appropriate of interactive learning multimedia of science designed for teaching, toward the students understanding on the microorganisms topic. This development research refers to the stages developed by Alessi \& Trollip. The development design used in this research is divided into 3 stages namely: (a) planning, (b) designing, and (c) developing. The results show the following results. (1) The material expert assessed the aspects of learning and material aspects with good category (scale 4.15), the media experts judged the aspects of the media in good category (scale 4.2), and students (user) assessed the aspects of learning, material, and media aspects with very good category (scale 4.5). Results suggest that interactive learning multimedia are considered good as a learning material for junior high school students. (2) The results of field trials (pretest and post test results) show that this medium is appropriate for improving learners' understanding on the microorganism topic.
\end{abstract}

Keywords: interactive learning multimedia, microorganisms 


\section{Pendahuluan}

Pembelajaran IPA di SMP/MTs pada hakikatnya merupakan cara mencari tahu tentang alam secara sistematis, sehingga IPA bukan hanya penguasaan kumpulan pengetahuan yang berupa fakta-fakta, konsep-konsep, atau prinsip-prinsip saja, tetapi juga merupakan suatu proses penemuan. Tujuan umum dari pembelajaran IPA adalah untuk mempersiapkan siswa dengan pengetahuan dasar, kemampuan dan sikap yang akan membawa siswa menuju kemandirian dan bermanfaat bagi kehidupannya di masyarakat tempat ia tinggal (Samikwo, 2013, p. 4296).

Hasil wawancara yang dilakukan pada bulan Oktober - November 2016 dengan siswa kelas VII di SMPN 1 Wates, diketahui bahwa siswa beranggapan bahwa pembelajaran IPA terasa sulit dan kurang menarik. Dalam pembelajaran IPA, siswa dituntut untuk memahami berbagai jenis istilah dalam bahasa Indonesia maupun dalam bahasa Latin. Selain itu cakupan materi yang sangat banyak yang harus mereka pelajari dalam kurun waktu 1 semester membuat siswa kewalahan dalam memahami materi itu sendiri. Hal ini senada dengan apa yang diungkapkan oleh Ekici (2010, p. 2137) yaitu bahwa dalam pelajaran sains (IPA), pada beberapa materi, dibutuhkan waktu sampai bertahuntahun untuk mempelajarinya, itulah alasannya kenapa siswa harus berusaha untuk benar-benar mempelajari subjek IPA.

Dalam mempelajari IPA, siswa lebih tertarik untuk diajak melakukan eksperimen ataupun observasi di lingkungan sekitar. Namun penerapan metode belajar dengan eksperimen ataupun observasi jarang dilakukan. Hal tersebut dikarenakan untuk melakukan eksperimen ataupun observasi dibutuhkan lebih banyak waktu, sedangkan ketersediaan waktu pembelajaran sangatlah terbatas. Berdasarkan wawancara dengan beberapa guru mata pelajaran IPA diketahui bahwa pembelajaran di kelas masih menggunakan metode belajar yang berpusat pada guru (teacher centered teaching).
Dalam proses pembelajaran IPA, guru seringkali menggunakan media power point di samping menggunakan buku cetak. Namun banyak siswa yang menyatakan bahwa penggunaan power point dalam pembelajaran seringkali membuat mereka bosan, mengantuk dan malas. Ketika proses pembelajaran, siswa cenderung malas untuk mencatat di buku catatan mereka. Siswa lebih cenderung untuk meminta soft copy atau file dari materi yang sudah ditayangkan. Media power point yang dikembangkan oleh guru bersifat satu arah (bukan media slide power point interaktif). Hal ini menyebabkan siswa kurang aktif dan hanya melihat atau mendengarkan penjelasan dari guru (Rusdewanti \& Gafur, 2014, p. 155). Padahal penggunaan media pembelajaran baik berupa modul cetak, modul interaktif, ataupun e-learning dimaksudkan untuk membantu terjadinya proses pembelajaran yang lebih efektif dan efisien.

Selain media power point guru belum pernah membuat ataupun mendesain media pembelajaran lainnya. Hal ini dikarenakan dapat menyebabkan persiapan dalam mengajar menjadi lebih lama dan menambah beban tugas guru dalam mencari atau membuat media yang sesuai dengan materi. Di samping itu guru belum mampu membuat dan mengembangkan software pembelajaran, seperti multimedia pembelajaran interaktif, yang dapat membuat siswa lebih berinteraksi aktif selama proses pembelajaran. Guru pernah mencari media pembelajaran seperti software pembelajaran IPA dalam bentuk multimedia pembelajaran interaktif yang dijual di pasaran. Namun, CD-CD pembelajaran yang dijual di pasaran tidak lengkap atau cakupan materi di dalamnya pun kurang relevan atau tidak lengkap serta tidak sesuai dengan kurikulum yang digunakan di sekolah, yaitu $\mathrm{Ku}-$ rikulum 2013.

Pembelajaran IPA harus dimulai dengan menghadapkan siswa kepada masalah-masalah nyata yang dapat diterapkan dalam kehidupannya, sehingga siswa diharapkan dapat memperoleh pengetahuan dan menguasai konsep IPA dengan lebih 
mendalam. Kenyataannya tidak semua objek dan gejala-gejala alam dapat dihadirkan dalam pembelajaran di kelas dan sulit dipelajari langsung karena terkendala dalam beberapa hal, misalnya waktu, peralatan, tenaga, dan tempat (Wahyuni \& Djukri, 2015 , p. 80). Berdasarkan wawancara dengan guru mata pelajaran IPA, contoh materi yang objek dan gejala-gejalanya sulit dipelajari langsung adalah materi Sistem Pencernaan Makanan, Sistem Pernafasan, Sistem Peredaran Darah, Klasifikasi Makhluk Hidup, Sistem Ekskresi, Sistem Pencernaan pada Manusia, serta Cara Tumbuhan Memperoleh Energi (Fotosintesis).

Materi Klasifikasi Makhluk Hidup memiliki cakupan materi tentang sejarah dan tujuan klasifikasi, kunci determinasi, mikroorganisme, kingdom plantae dan kingdom animalia. Karena cakupan materi yang sangat banyak sedangkan waktu pembelajaran yang tersedia terbatas, maka guru dalam memberikan materi Klasifikasi Makhluk Hidup selama ini lebih banyak menggunakan metode penugasan yang berupa pengerjaan soal-soal ataupun membuat rangkuman. Sayangnya, penggunaan metode penugasan tersebut membuat siswa kurang atau belum memahami materi. Hal ini dapat dilihat dari hasil ulangan harian untuk pokok bahasan tersebut. Dimana untuk hasil ulangan tertinggi yang diperoleh siswa yaitu 82 dan hasil terendah 34. Adapun skor rata-rata tiap kelas adalah 58. Hasil ini tentu masih rendah mengingat nilai KKM di SMP Negeri 1 Wates untuk mata pelajaran IPA adalah 75 .

Mikroorganisme merupakan materi yang mempelajari tentang makhluk hidup yang berukuran mikro (kecil). Materi ini sangat dekat dengan kehidupan sehari-hari siswa. Objek-objek belajarnya pun banyak tersedia di lingkungan sekitar siswa. Ketersediaan objek belajar yang mudah ditemui akan mempermudah pembelajaran. Akan tetapi untuk dapat melihat dan mempelajari objek materi mikroorganisme ini diperlukan peralatan yang memadai. Untuk dapat melihat mikroorganisme secara jelas diperlukan mikroskop elektron. Sayangnya, mikroskop jenis ini tidak tersedia di sekolah. Dengan ketiadaan prasarana yang memadai, siswa hanya dapat melihat satu atau dua jenis mikroorganisme sebagai bentuk bulatan atau mirip potongan benang. Dalam mempelajari materi ini siswa hanya disuguhkan gambar-gambar bentuk mikroorganisme, sehingga pembelajaran menjadi kurang bermakna dibandingkan jika siswa dapat melihat langsung objek dan gejalagejala mikroorganisme. Siswa dapat mengagumi keteraturan dan kompleksitas ciptaan Tuhan jika siswa melihat langsung objek dan gejala-gejala mikroorganisme.

Permasalahan lainnya ialah tentang pemanfaatan fasilitas sekolah sebagai media pembelajaran yang belum optimal. Keberadaan laboratorium komputer belum digunakan sebagai tempat alternatif belajar. Laboratorium komputer hanya digunakan untuk pembelajaran TIK. Guru mata pelajaran IPA menyatakan bahwa menjadikan media pembelajaran dengan bantuan komputer sangat mungkin untuk dilakukan dalam pembelajaran, namun keterbatasan media pembelajaran interaktif menjadi suatu kendala. Padahal minat belajar menggunakan komputer berdasarkan pengamatan guru cukup tinggi.

Menyikapi permasalah tersebut, agar pembelajaran IPA menjadi berkualitas dan tidak terus-menerus berdampak pada rendahnya kualitas pembelajaran, maka peneliti melihat adanya kebutuhan untuk mengembangkan media dalam pembelajaran IPA, yaitu dalam bentuk multimedia pembelajaran interaktif yang dikemas dalam bentuk CD untuk materi Mikroorganisme. Multimedia pembelajaran interaktif ini menyajikan materi mikroorganisme dalam tampilan animasi dan video sehingga dapat meningkatkan pemahaman siswa pada materi mikroorganisme, dan mampu menggantikan pengalaman pembelajaran langsung.

Permasalahan dalam penelitian ini adalah Bagaimana kelayakan produk multimedia pembelajaran interaktif materi mikroorganisme sebagai media pembelajaran IPA kelas VII SMP? Apakah multimedia 
pembelajaran interaktif materi mikroorganisme mampu meningkatkan pemahaman siswa pada materi mikroorganisme?

Adapun tujuan dari penelitian ini adalah untuk mengetahui kriteria kelayakan produk multimedia pembelajaran interaktif materi mikroorganisme sebag media pembelajaran IPA kelas VII di SMP, dan untuk mengetahui apakah multimedia pembelajaran interaktif IPA yang dikembangkan mampu meningkatkan pemahaman siswa pada materi mikroorganisme.

\section{Metode Penelitian}

Penelitian ini merupakan penelitian pengembangan atau Education Research and Development (RED). Model pengembangan yang digunakan dalam mengembangkan multimedia pembelajaran interaktif adalah model pengembangan Alessi \& Trollip (2001, p. 410). Langkah-langkah pengembangan terdiri dari 3 tahapan yaitu perencanaan (planning), desain (design), dan pengembangan (development).

Pada tahapan perencanaan dilakukan penentuan ruang lingkup materi pembelajaran mikroorganisme berdasarkan silabus yang digunakan guru mata pelajaran IPA di SMP Negeri 1 Wates, mengidentifikasi karakteristik siswa dengan menggunakan teknik wawancara baik dengan guru maupun siswa, mengumpulkan sumbersumber yang mendukung pengembangan multimedia pembelajaran interaktif IPA pada materi mikroorganisme, melakukan brainstorming (diskusi ide awal) dengan guru mata pelajaran IPA, teman sejawat dan dosen ahli materi dan dosen ahli media. Selanjutnya adalah membuat dokumen perencanaan seperti tampilan produk dan rencana pelaksanaan pembelajaran (RPP).

Pada tahap desain, langkah yang dilakukan yaitu membuat flowchart dan storyboard, serta menyiapkan naskah materi. Pada tahap pengembangan terdiri dari empat langkah, yaitu (1) menyiapkan elemen-elemen produk. Elemen-elemen produk yang digunakan dalam pengembangan multimedia interaktif ini terdiri dari gambar, animasi, audio dan video. Untuk pengolahan gambar dilakukan dengan menggunakan program Adobe Photoshop CS2, untuk pengolahan animasi menggunakan program Adobe Flash CS5, untuk pengolahan audio menggunakan program Audacity, dan untuk pengolahan video menggunakan Adobe After Effect; (2) membuat produk. Pembuatan produk dilakukan dengan menggabungkan elemen-elemen produk yang sudah dikumpulkan dan diolah. Penggabungan elemen-elemen ini dilakukan dengan menggunakan software Adobe Flash CS5 yang disesuaikan dengan flowchart dan storyboard. Setelah penggabungan elemen-elemen media selesai, selanjutnya dilakukan pengemasan produk sehingga menghasilkan multimedia pembelajaran interaktif IPA materi mikroorganisme yang dikemas dalam bentuk $C D$ (Compact Disc). Lalu pembuatan sampul kemasan luar dan dalam yang didesain dengan menggunakan aplikasi Corel Draw X7. Pada sampul luar CD tertera identitas program, manfaat program, dan cara penggunaan multimedia pembelajaran interaktif ini; (3) melakukan uji alpa,uji beta, serta revisi produk. Uji alfa yaitu validasi produk yang dilakukan oleh dua ahli media dan dua ahli materi. Setelah dilakukan uji alfa, kemudian dilanjutkan dengan revisi awal. Revisi awal dilakukan berdasarkan pada penilaian dan masukan-masukan yang didapat dari ahli media maupun ahli materi.Uji beta dilakukan kepada 6 orang siswa SMP Kelas VII dimana dua siswa memiliki kemampuan intelektual tinggi, dua siswa memiliki kemampuan intelektual sedang, dan dua siswa memiliki kemampuan intelektual rendah. Pemilihan 6 orang responden ini berdasarkan rekomendasi dari guru mata pelajaran IPA. Setelah uji beta dilakukan, kemudian produk direvisi terakhir. Revisi terakhir ini bertujuan untuk memperbaiki produk sehingga tidak ada lagi kesalahan dan siap digunakan untuk uji lapangan (validasi produk). (4) melakukan uji coba lapangan (validasi produk). Setelah produk disempurnakan, tahap selanjutnya adalah melakukan uji 
lapangan (validasi produk). Validasi produk bertujuan untuk mengetahui tanggapan siswa dan menguji kebermanfaatan produk melalui tes capaian hasil belajar.

Desain uji coba produk dalam penelitian pengembangan ini meliputi: desain uji coba, subjek uji coba, jenis data, teknik dan instrumen pengumpulan data, dan teknis analisis data. Uji coba produk dibagi menjadi tiga tahapan, yaitu uji alfa, uji beta, dan uji lapangan. Uji alfa bertujuan agar produk multimedia yang dikembangkan memenuhi kriteria-kriteria kelayakan produk multimedia pembelajaran baik dari segi isi dan pembelajarannya, kualitas medianya, maupun keterpakaiannya dalam proses pembelajaran. Uji beta ditujukan untuk mendapatkan tanggapan kualitatif awal dari pengguna meliputi kenyamanan pemakaian produk, ketersampaian pesan pembelajaran dan kelengkapan produk. Uji lapangan ditujukan untuk mengetahui apakah produk yang dikembangkan dapat diterapkan dalam situasi pembelajaran kelas dimana terdapat siswa dengan kecepatan belajar yang beragam. Adapun desain uji coba dapat dilihat pada Gambar 1.

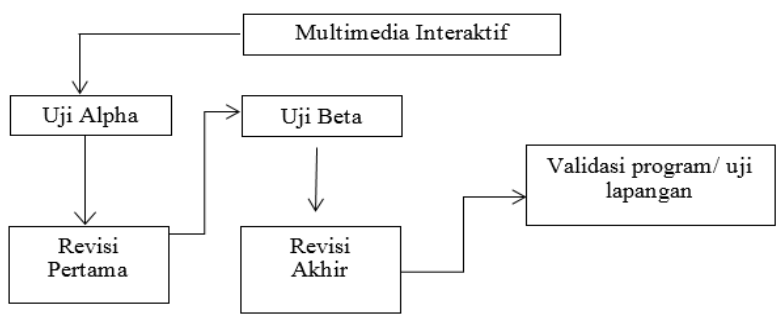

Gambar 1. Desain Uji Coba

Subjek penelitian untuk uji alfa adalah enam siswa kelas VII SMP Negeri I Wates Tahun pelajaran 2016/2017, yang terdiri dari 2siswa berkemampuan tinggi, 2 siswa berkemampuan sedang, dan 2 siswa berkemampuan rendah. Subjek uji coba lapangan adalah kelas VII F dengan jumlah siswa 30 orang.

Instrumen yang digunakan untuk mengumpulkan data terdiri dari kuesioner kelayakan multimedia pembelajaran interaktif oleh ahli media, ahli materi, dan peng- guna (siswa). Instrumen lainnya yaitu berupa soal pretest dan soal postest. Kuesioner kelayakan digunakan untuk memvalidasi dan mengevaluasi kualitas produk yang dikembangkan baik dari aspek materi pembelajaran, aspek tampilan media, dan aspek interaksi dengan media. Soal pretes dan soal posttest terdiri dari 20 butir soal pilihan ganda. Instrumen soal pretes dan posttest ini divalidasi dengan expert judgement.

Teknik analisis data kualitatif yang berupa kritik dan saran dari yang dikemukakan oleh ahli media, ahli materi dan pengguna (siswa) pada saat uji alfa, uji beta dan validasi program dihimpun dan disarikan sebagai pedoman untuk memperbaiki multimedia interaktif yang dikembangkan.

Data kuantitatif yang diperoleh dari hasil penilaian ahli materi, ahli media, pengguna (siswa) dianalisis menggunakan statistik deskriptif kualitatif. Teknik analisis data menggunakan statistik deskriptif yang kemudian dikonversikan menjadi data kualitatif skala 5 (Skala Likert). Kualitas multimedia yang digambarkan oleh rerata ( $\bar{x})$ nilai hasil uji coba dalam penelitian. Nilai rerata yang diperoleh dikategorikan dalam kualitas pada skala 1-5 dengan menggunakan batas yang membagi skala tersebut dalam lima bagian yang sama dengan acuan rumus yang dikutip dari Jumasa \& Surjono (2016, p. 29) pada Tabel 1.

Tabel 1. Kriteria Penilaian elayakan Multimedia Interaktif

\begin{tabular}{clc}
\hline Nilai & Kategori & Rentang Skor \\
\hline 5 & Sangat layak & $\bar{X}_{\iota}+1,8 S d_{i}<X$ \\
4 & Layak & $\bar{X}_{l}+0,6 S d_{i}<X \leq \bar{X}_{l}+1,8 S d_{i}$ \\
3 & Cukup & $\bar{X}_{l}-0,6 S d_{i}<X \leq \bar{X}_{l}+0,6 S d_{i}$ \\
2 & Kurang & $\bar{X}_{l}-1,8 S d_{i}<X \leq \bar{X}_{l}-0,6 S d_{i}$ \\
1 & Sangat kurang & $X \leq \bar{X}_{l}-1,8 S d_{i}$ \\
\hline
\end{tabular}

Ketentuan:

$\bar{X}_{l} \quad$ : Rerata skor ideal

$1 / 2$ (skor maksimal + skor minimal)

$S d_{i}:$ Standar Deviasi Ideal

1/6 (skor maksimal - skor minimal)

$\mathrm{X}$ : skor empiris

Untuk uji signifkansi hasil belajar siswa dilakukan uji statistik independent t- 
test dengan menggunakan program SPSS 23. Taraf signifikansi yang digunakan adalah $5 \%$, dengan kriteria keputusan produk memberikan perbedaan signifikan dalam meningkatkan capaian hasil belajar kognitif siswa pada materi mikroorganisme apabila signifikansi kurang dari taraf signifikansi 5\%.

\section{Hasil Penelitian dan Pembahasan}

Hasil Pengembangan

\section{Tahap Perencanan}

Tahap perencanaan merupakan kegiatan awal yang dilakukan dalam penelitian ini. Tahap perencanaan dilakukan pada bulan Oktober - November 2015. Dimana hasil yang diperoleh dalam rangkaian tahap ini adalah menentukan ruang lingkup materi mikroorganisme dan identifikasi karakter siswa kelas VII SMP N 1 Wates. Pada tahap perencanaan dilakukan beberapa langkah.

Pertama yaitu pengumpulan sumber yang dilakukan dengan mengumpulkan materi ajar dan software yang akan dibutuhkan dalam pengembangan multimedia pembelajaran interaktif IPA ini yaitu menggunakan sofware Adobe Flash CS5, Corel Draw X7, Audacity, Adobe After Effect, Adobe Photoshop CS2, dan Microsoft Word 2013. Kedua, melakukan brainstorming dengan guru pengampu mata pelajaran IPA dan siswa kelas VII di SMPN 1 Wates, rekan sejawat, dan dosen Biologi di Universitas Negeri Yogyakarta. Adapun hal-hal yang didiskusikan yaitu mengenai tampilan media, warna, jenis musik, gambar, animasi, dan video yang digunakan untuk menguatkan penjelasan konsep materi dalam multimedia. Ketiga, membuat dokumen perencanaan yang berupa rencana tampilan produk dan RPP. Penetapan rencana tampilan dilakukan untuk mempermudah dalam mendesain multimedia pembelajaran interaktif. Dengan adanya penetapan rencana tampilan ini, maka elemen-elemen yang akan dimasukkan ke dalam multimedia, seperti teks, gambar, video, dan animasi, akan menjadi lebih tepat dan tertata rapi. Setelah rencana tampilan di tetapkan, maka selanjutnya dilakukan pencarian setiap elemen-elemen media yang telah direncanakan.

\section{Tahap Desain}

Jenis-jenis kegiatan yang dilakukan pada tahap ini adalah pembuatan flowchart, storyboard, dan perancangan naskah materi. Flowchart memuat panduan dalam pengembangan multimedia pembelajaran interaktif yang memberikan arahan bagaimana fungsi dan keterkaitan antara bagian-bagian yang ada dalam multimedia pembelajaran. Storyboard memuat hal-hal yang dituangkan pada tiap halaman dalam multimedia pembelajaran interaktif ini. Storyboard dipersiapkan sebagai gambaran visual awal dari multimedia pembelajaran yang dikembangkan. Gambaran visual awal tersebut meliputi tata letak, tampilan tombol, teks, animasi, dan video. Untuk mempersiapkan teks yang dimasukkan dalam multimedia pembelajaran interaktif ini dilakukan dengan menggunakan program pengelola kata Microsoft Word 2013.

\section{Tahap Pengembangan}

Jenis-jenis kegiatan yang dilakukan pada tahap ini adalah penyiapan elemenelemen media yang digunakan yang meliputi gambar, animasi, audio, video. Gambar tombol ikon, gambar tangan, gambar lingkungan, serta gambar berbagai jenis dan bentuk mikroorganisme disiapkan dan dikelola dengan menggunakan software pengelola gambar yaitu Corel Draw X7 dan Adobe Photoshop CS2. Pembuatan animasi pada multimedia pembelajaran ini menggunakan program Adobe Flash CS5. Audio yang ada pada multimedia pembelajaran interaktif ini meliputi musik instrumen yang diperoleh dari internet, narasi yang diperoleh dari hasil perekaman dan diolah dengan program Audacity, serta audio tombol digunakan untuk memberikan efek suara ketika tombol-tombol dalam multime- 
dia ini disorot/dipilih. Video yang digunakan pada pengembangan multimedia pembelajaran interaktif IPA ini diperoleh dari situs www.youtube.com. Video yang digunakan dalam multimedia ini meliputi (1) video keberagaman makhluk hidup di kolam yang digunakan sebagai apersepsi, (2) video tentang perbedaan antara sel prokariot dan sel eukariot, (3) video tentang keberagaman bakteri, dan (4) video tentang keberagaman protista.

Video yang didapatkan merupakan video dengan teks berbahasa Inggris. Untuk itu dilakukan pengeditan video dengan cara menambahkan teks terjemahan bahasa Indonesia dengan menggunakan program Adeobe After Effect.

Setelah tahap penyiapan elemen kemudian dilanjutkan pada tahap penggabungan. Tahap penggabungan multimedia pembelajaran interaktif IPA ini dilakukan dengan menggunakan software Adobe Flash CS5 yang disesuaikan dengan flowchart dan storyboard. Adapun komponen-komponen multimedia ini, yaitu desain visual, teks, grafiks, penggunaan warna, layout

Tampilan desain visual pada multimedia pembelajaran ini meliputi halaman splashcreen dan halaman judul (tittle page) yang menerapan teori Chijiwa (Prawira, Sulasmi, 1989, pp. 51-52). Terdapat 2 jenis grafik dalam multimedia ini, yaitu static visual display (gambar) dan dynamic visual display (animasi/video). Penggunaan warna (use of colour) menerapan teori menurut Phillips (1997, pp. 84-87). Penggunaan warna dalam multimedia pembelajaran interaktif adalah warna teks, dan warna background. Untuk warna background digunakan warna kelabu, sedangkan warna teks yang digunakan adalah warna putih untuk tulisan materi dan warna kuning untuk judul materi. Penggunaan warna juga digunakan sebagai penanda bagian-bagian tampilan seperti warna yang berbeda untuk tombol home, bantuan, next, back, dan exit.

Menurut Philips (1997, p. 79 - 80) yang menyebutkan bahwa tata letak hendaknya harus mempertimbangkan kesetimbangan letak unsur utama dan tersusun pada sebuah shape yang mencukup, menjadi acuan dalam pengembangan multimedia pembelajaran ini.

Menurut Tan \& Wong (2003, p. 57) tentang menu dalam multimedia pembelajaran adalah pembuatan menu yang mudah diakses. Menu utama ditampilkan secara jelas sehingga pengguna dapat langsung memilih menu yang diinginkan dan terdapat tombol home yang terletak di pojok kanan bawah untuk membawa pengguna menuju ke pilihan utama, juga terdapat tombol exit yang terletak di pojok kanan bawah untuk membawa pengguna keluar dari program.

Menurut Alessi \& Trollip (2001, pp. 53-54) tentang icons dan navigation buttons dalam multimedia pembelajaran adalah pemberian tombol/menu yang dibutuhkan dalam presentasi materi, fungsi masingmasing tombol jelas karena dilengkapi dengan konfirmasi berupa efek pergantian warna dan suara ketika tombol di sorot

Penggabungan bagian-bagian dalam multimedia ini juga memperhatikan prinsip desain multimedia pembelajaran menurut Meyer (2009). Prinsip-prinsip yang digunakan adalah (1) Prinsip multimedia, siswa dapat belajar lebih baik dari kata-kata dan gambar-gambar dari pada kata-kata saja; (2) Prinsip keterdekatan ruang, siswa dapat belajar lebih baik saat kata-kata dan gambar-gambar terkait disajikan saling berdekatan daripada saat disajikan saling berjauhan dalam halaman atau layar; (3) Prinsip keterdekatan waktu, siswa dapat belajar lebih baik saat kata-kata dan gambargambar terkait disajikan secara simultan daripada bergantian; (4) Prinsip koherensi, siswa dapat belajar lebih baik jika materi yang tidak relevan tidak dimasuk-kan ke dalam multimedia pembelajaran. Prinsip ini dijabarkan menjadi tiga versi yang saling melengkapi, yaitu (a) pembelajaran siswa akan terganggu jika kata-kata dan gambar-gambar menarik namun tidak relevan ditambahkan ke dalam multimedia, (b) pembelajaran siswa akan terganggu jika suara dan musik menarik namun tidak relevan ditambahkan ke dalam multime- 
dia, (c) pembelajaran siswa akan meningkat jika kata-kata yang tidak diperlukan dihilangkan dari multimedia; (5) Prinsip modalitas, siswa dapat belajar lebih baik dari animasi dan narasi daripada dari animasi dan teks on-screen; (6) Prinsip redudansi, siswa belajar lebih baik dari animasi dan narasi daripada dari gabungan animasi, narasi dan teks yang identik sama dengan narasi. Penerapan dalam multimedia ini adalah dengan memberikan animasi, dan narasi dalam satu frame secara bersamaan; (7) Prinsip interaktifitas, siswa belajar lebih baik ketika mereka dapat mengendalikan sendiri apa yang sedang dipelajari. Adapun bentuk interaktivitas dapat berupa self control, simulasi, game, dan branching. Penerapan dalam multimedia yang dikembangkan ini adalah pengguna bisa memilih apa yang akan mereka pelajari tanpa harus berurutan dari awal.

Setelah penggabungan elemen-elemen selesai maka tahap selanjutnya adalah melakukan tes modular. Tes secara modular dilakukan untuk memastikan apakah media yang dikembangkan sesuai dengan flowchart dan storyboard yang direncanakan. Tes modular dilakukan pada beberapa komputer lain untuk mengetahui jalannya program secara keseluruhan. Langkah terakhir adalah pengemasan produk. Sampul kemasan luar dan dalam dari CD (Compact Disc) multimedia pembelajaran interaktif ini didesain dengan menggunakan aplikasi Corel Draw X7. Pada sampul luar dari CD pembelajaran ini tertera identitas program, sasaran pengguna, dan lembaga pengembang program.

\section{Hasil dan Analisis Data Uji Coba Produk}

\section{Uji Alfa (Alpha Testing)}

Tahap uji alfa yang dilakukan kepada 2 orang ahli media dan 2 orang ahli materi. Tahap ini dimaksudkan untuk mengetahui tingkat kelayakan produk yang dihasilkan berdasarkan penilaian para ahli. Hasil validasi dari ahli media dapat dilihat pada Tabel 2.
Tabel 2. Hasil Penilaian Ahli Media

\begin{tabular}{|c|c|c|c|c|c|}
\hline \multirow{2}{*}{ No } & \multirow{2}{*}{ Komponen } & \multicolumn{2}{|c|}{ Penilaian } & \multirow{2}{*}{ Rerata } & \multirow{2}{*}{ Kriteria } \\
\hline & & 1 & 2 & & \\
\hline 1 & Aspek pemrograman & 4.1 & 4.3 & 4.2 & Layak \\
\hline 2 & Aspek tampilan & 4.1 & 4.2 & 4.1 & Layak \\
\hline & Rerata Penilaian & & & 4.2 & Layak \\
\hline
\end{tabular}

Kriteria penilaian multimedia pada aspek tampilan didasari oleh pendapat yang dikemukakan oleh Philips (1997) dan Meyer (2009), yaitu meliputi tata letak, teks, grafis, warna, animasi, suara dan bagaimana menempatkan elemen-elemen media agar dapat menjadi penyalur pesan yang baik. Hal ini sesuai dengan karakteristik multimedia pembelajaran yang dikemukan oleh Daryanto (2010, pp. 53-54) yang mengungkapkan bahwa multimedia yang dibuat harus memiliki karakteristik menggabungkan unsur audio dan visual.

Kriteria penilaian multimedia pada aspek pemrograman didasari oleh pendapat Alessi \& Trollip (2001, pp. 53-54) bahwa multimedia yang baik adalah multimedia yang memiliki struktur navigasi yang baik, konsiten tempat dan bentuknya. Hal senada juga diungkapkan oleh Daryanto (2010, pp. 53-54) bahwa multimedia pembelajaran harus bersifat interaktif, dalam pengertian memiliki kemampuan untuk mengakomodasi respon pengguna; serta bersifat mandiri, dalam pengertian memberi kemudahan dan kelengkapan isi sedemikian rupa sehingga pengguna bisa menggunakan tanpa bimbingan orang lain.

Secara keseluruhan penilaian ahli media pada semua aspek menghasilkan rerata sebesar 4,2 (Layak). Perolehan nilai ini menunjukkan multimedia pembelajaran interaktif yang dikembangkan sudah mengikuti kriteria multimedia yang baik dari aspek tampilan dan pemograman. Dan hasil tersebut mennunjukkan bahwa produk yang dikembangkan layak digunakan sebagai media pembelajaran IPA materi mikroorganisme untuk siswa SMP Kelas VII dengan melakukan perbaikan pada bagianbagian sesuai saran dari para ahli media. 
Data hasil validasi kelayakan oleh ahli materi dapat dilihat pada Tabel 3.

Tabel 3. Hasil Penilaian Ahli Materi

\begin{tabular}{|c|c|c|c|c|c|}
\hline \multirow{2}{*}{ No } & \multirow{2}{*}{ Komponen } & \multicolumn{2}{|c|}{ Penilaian } & \multirow{2}{*}{ Rerata } & \multirow{2}{*}{ Kriteria } \\
\hline & & 1 & 2 & & \\
\hline 1 & Aspek pembelajaran & 4.1 & 4.3 & 4.2 & Layak \\
\hline 2 & Aspek isi/materi & 4.1 & 4.1 & 4.1 & Layak \\
\hline \multicolumn{4}{|c|}{ Rerata Penilaian } & 4.15 & Layak \\
\hline
\end{tabular}

Kriteria penilaian multimedia oleh ahli materi didasari oleh pendapat Tan \& Wong (2003, p. 143) dan Heinich, Molenda, Russel, \& Smaldino (1996, p. 47). Secara keseluruhan penilaian ahli materi pada semua aspek menghasilkan rerata sebesar 4,15 (Layak). Perolehan nilai ini menunjukkan multimedia pembelajaran interaktif yang dikembangkan sudah layak digunakan sebagai media pembelajaran IPA materi mikroorganisme untuk siswa SMP Kelas VII dengan melakukan perbaikan pada bagian-bagian sesuai saran dari para ahli materi. Hal ini sesuai dengan fungsi multimedia pembelajaran yang dilakukan oleh Marsana (2013, p. 135) yaitu multimedia pembelajaran yang digunakan dapat menanamkan konsep benar, nyata, dan tepat.

Data hasil uji beta dapat dilihat pada Tabel 4 .

Tabel 4. Hasil Penilaian Uji Beta

\begin{tabular}{|c|c|c|c|c|c|c|c|c|c|}
\hline \multirow{2}{*}{ No } & \multirow{2}{*}{ Komponen } & \multicolumn{6}{|c|}{ Penilaian } & \multirow{2}{*}{ Rerata } & \multirow{2}{*}{ Kriteria } \\
\hline & & 1 & 2 & 3 & 4 & 5 & 6 & & \\
\hline 1 & $\begin{array}{l}\text { Aspek } \\
\text { pembelajaran }\end{array}$ & 5.0 & 4.5 & 4.8 & 4.9 & 4.8 & 4.9 & 4.8 & $\begin{array}{l}\text { Sangat } \\
\text { layak }\end{array}$ \\
\hline 2 & Aspek materi & 4.3 & 4.9 & 4.4 & 4.4 & 4.3 & 4.3 & 4.4 & $\begin{array}{l}\text { Sangat } \\
\text { layak }\end{array}$ \\
\hline 3 & Aspek media & 4.4 & 4.4 & 4.4 & 4.6 & 4.6 & 3.8 & 4.4 & $\begin{array}{l}\text { Sangat } \\
\text { layak }\end{array}$ \\
\hline \multicolumn{8}{|c|}{ Rerata Penilaian } & 4.5 & $\begin{array}{l}\text { Sangat } \\
\text { layak }\end{array}$ \\
\hline
\end{tabular}

Dari hasil penilaian uji beta tersebut menunjukkan bahwa besar rerata penilaian adalah 4,5 (sangat layak). Oleh karena itu multimedia pembelajaran interaktif ini sudah sangat layak untuk digunakan sebagai media pembelajaran IPA materi mikroorganisme untuk siswa SMP Kelas VII.
Data capaian hasil belajar kognitif siswa dapat dilihat dari pencapaian hasil belajar yang diperoleh siswa setelah menggunakan multimedia pembelajaran interaktif IPA (nilai posttest). Uji ini dilakukan terhadap 30 orang siswa kelas VII SMP N 1 Wates. Sebelum menggunakan produk, siswa diberikan tes (pretest) untuk melihat pengetahuan siswa sebelum menggunakan produk.

Analisis data capaian hasil belajar kognitif ini dimaksudkan untuk mengetahui sejauh mana tingkat pencapaian hasil belajar kognitif siswa pada materi mikroorganisme. Adapun skor kompetensi minimal yang harus dikuasai oleh siswa pada materi mikroorganisme di SMP N 1 Wates adalah 75 .

Berdasarkan data yang diperoleh, didapati bahwa rata-rata nilai pretest siswa sebelum menggunakan multimedia pembelajaran interaktif adalah 41,3 . Sedangkan hasil postest siswa setelah menggunakan multimedia pembelajaran interaktif adalah 80,5 . Siswa yang memperoleh capaian hasil belajar kognitif melewati batas ketuntasan minumum adalah $83 \%$. Hal ini menunjukkan bahwa produk yang digunakan dapat meningkatkan pemahaman siswa pada materi mikroorganisme.

Data hasil belajar kognitif pada saat pretest dan posttest terlihat pada Gambar 2.

Data hasil pretest dan posttest kemudian dianalisis menggunakan program SPSS 23 dengan uji statistik paired sampel $t$ test. Taraf signifikansi yang digunakan adalah 5\%, dengan kriteria keputusan produk yang memberikan perbedaan signifikan dalam meningkatkan pemahaman siswa pada materi mikroorganisme apabila signifikansi kurang dari taraf signifikansi 5\%.

Berdasarkan hasil analisis uji statistik paired sampel $t$-test yang telah dilakukan diperoleh nilai signifikansi yaitu 0,000 (kurang dari taraf signifikansi 5\%). Hal tersebut menunjukkan bahwa multimedia pembelajaran interaktif ini terbukti signifikan dalam meningkatkan pemahaman siswa pada materi mikroorganisme. 


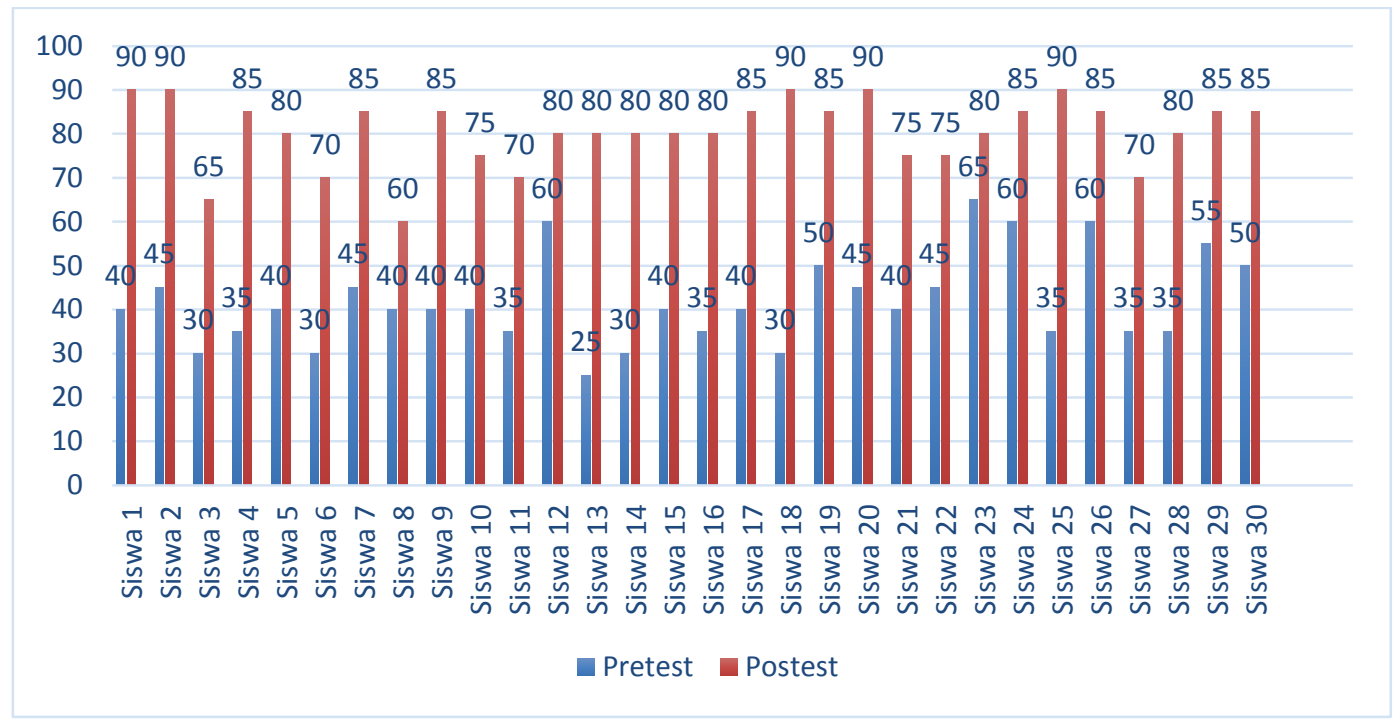

Gambar 2. Diagram Perbandingan Hasil Pretest dan Postest

Bukti lain yang juga dapat memperkuat simpulan di atas adalah ketika hasil belajar kognitif siswa yang menggunakan bantuan belajar dengan multimedia pembelajaran interaktif dibandingkan dengan hasil belajar tahun sebelumnya, dimana siswa sebelumnya belum menggunakan multimedia pembelajaran interaktif, namun telahsama-sama mendapatkan materi mikroorganisme.

Tabel 5. Perbandingan Hasil Belajar Kognitif

\begin{tabular}{lcccc}
\hline No. & $\begin{array}{c}\text { Tahun } \\
\text { Pelajaran }\end{array}$ & Kelas & $\begin{array}{c}\text { Jumlah } \\
\text { Siswa }\end{array}$ & $\begin{array}{c}\text { Hasil Belajar } \\
\text { Materi } \\
\text { Mikroorganisme }\end{array}$ \\
\hline 1. & $2015 / 2016$ & VIIF & 30 & 61 \\
2. & $2016 / 2017$ & VIIF & 30 & 80,5 \\
\hline
\end{tabular}

Diasumsikan kemampuan awal dan karakteristik siswa sama, dari data pada tabel 5dapat dilihat bahwa kenaikan hasil belajar materi mikroorganisme dari 30 orang siswa pada tahun pelajaran 2016/ 2017 mengalami peningkatan menjadi 80,5. Penilaian hasil belajar yang digunakan adalah menggunakan skala 100.

Kajian Produk Akhir

Produk yang dikembangkan adalah multimedia pembelajaran interaktif IPA pa- da materi mikroorganisme, sasaran produk adalah siswa kelas VII SMP dan sederajat. Pengembangan produk dilakukan melalui 3 tahap yaitu tahap perencanaan, tahap desain, dan tahap pengembangan. Tujuan dari penelitian ini yaitu untuk menghasilkan produk multimedia pembelajaran interaktif IPA yang layak dalam pencapaian tujuan pembelajaran pada materi mikroorganisme di SMP Negeri 1 Wates.

Karakteristik produk yang dihasilkan pada penelitian pengembangan ini adalah produk dapat menggantikan pengalaman belajar langsung dimana siswa dapat menyaksikan berbagai jenis mikroorganisme dalam tampilan video dan animasi, produk tersusun atas beberapa jenis media yang aktifitas penggunaannya dapat dikontrol secara mandiri oleh siswa, produk dibuat untuk memenuhi kecepatan belajar siswa dalam memahami materi mikroorganisme, produk dikemas dalam bentuk software aplikasi yang dapat dijalankan pada berbagai jenis komputer ataupun laptop.

Produk yang dihasilkan terbukti layak untuk digunakan dalam pembelajaran IPA materi mikroorganisme berdasarkan uji kelayakan menurut ahli media dan ahli materi. Produk yang dihasilkan juga dapat meningkatkan capaian hasil belajar kognitif siswa pada materi mikroorganisme. Ter- 
bukti dengan 83\% siswa mencapai hasil belajar lebih besar dari angka KKM (75). Dengan rata-rata capaian hasil belajar kognitif siswa sebesar 80,5. Serta dengan uji statistik independent-test yang menunjukkan peningkatan capaian hasil belajar siswa setelah menggunakan produk multimedia pembelajaran interaktif adalah signifikan.

Hal ini disebabkan karena dalam pengembangan multimedia ini telah menerapkan prinsip-prinsip multimedia, seperti pengunaan prinsip Meyer (2009), yang baik. Sehingga penggunaan produk mendukung penyampaian materi dan membuat siswa lebih mudah dan lebih tertarik dalam memahami materi mikroorganisme. Penggunaan multimedia yang dapat dikontrol sesuai dengan kecepatan pemahaman masing-masing siswa memberikan daya tarik tersendiri bagi siswa. Hal ini senada dengan yang diungkapkan oleh Sadiman, Rahardjo, Haryono, \& Rahardjito (2012, pp. 17-18) bahwa manfaat dari penggunaan media pendidikan secara tepat dapat menimbulkan kegairahan belajar, memungkinkan siswa belajar sendiri-sendiri menurut kemampuan dan minatnya. Arkün \& Akkoyunlu (2008, p. 11) menyatakan bahwa penggunaan media yang dapat dikontrol sendiri oleh siswa meningkatkan kegairahan siswa dalam belajar.

Peran multimedia pembelajaran interaktif tampak pada ketertarikan siswa untuk menggunakan produk selama pembelajaran berlangsung. Hal ini didukung oleh pendapat Newby, Stepich, Lehman, \& Russell (2000, p. 108) bahwa penggunaan multimedia memberikan manfaat motivasi, dimana siswa menunjukkan sikap positif yang konsisten terhadap multimedia pembelajaran. Hal senada juga diungkapkan oleh Leow \& Neo (2014, p. 99), dimana pada era sekarang ini, pendidik dilatih untuk mentransformasi pembelajaran yang berpusat pada guru pada pembelajaran yang berpusat pada siswa dengan menggunakan teknologi berbasis lingkungan. Dengan menggunakan teknologi maka siswa termotivasi untuk berpartisipasi aktif dan berinteraksi selama proses pembelajaran.
Kelebihan produk multimedia pembelajaran interaktif IPA materi mikroorganisme yang dihasilkan antara lain dalam penyajiannya, multimedia pembelajaran interaktif ini mengandung berbagai unsur, seperti teks, gambar, audio, video, animasi, dan interaktivitas, yang membantu siswa untuk aktif mengkontruksi pengetahuan dan pemahaman mereka, serta membuat siswa lebih tertarik dan termotivasi. File multimedia ini berbentuk .exe sehingga dapat dijalankan diberbagai jenis komputer atau laptop tanpa harus menginstal program Adobe Flash Player.Terdapat feedback (umpan balik) sehingga siswa termotivasi akibat adanya penghargaan yang diberikan. Membantu siswa mendapatkan pengganti pengalaman belajar langsung dimana siswa dapat menyaksikan video dan animasi berbagai mikroorganisme. Aktivitas belajar dapat dikontrol sendiri oleh siswa. Siswa dapat belajar sesuai kemampuan dan kecepatan belajarnya masing-masing dalam memahami pengetahuan dan informasi yang disajikan.

Penelitian pengembangan ini baru pada tahap kebermanfaatan penggunaan multimedia pembelajaran interaktif. Hal ini karena pada penelitian tidak dilakukan perbandingan dengan produk atau media pembelajaran lainnya. Terdapat keterbatasan kondisi pembanding capaian hasil belajar kognitif siswa tahun sebelumnya, misalnya keterbatasan kondisi pembanding dan tidak digunakannya produk atau media dalam pembelajaran. Produk multimedia pembelajaran yang dikembangkan baru sebatas dalam format file .exe, sehingga program hanya dapat dijalankan pada fasilitas komputer atau laptop. Produk multimedia pembelajaran yang dikembangkan hanya dirancang untuk membantu siswa pada satu pokok bahasan saja yaitu mikroorganisme, dan soal evaluasi hanya terbatas pada penilaian aspek kognitif.

\section{Simpulan}

Berdasarkan hasil penelitian dan pembahasan, maka dapat disamapaikan simpulan sebagai berikut. 
Kelayakan produk multimedia pembelajaran interaktif yang dihasilkan ditinjau dari aspek pemrograman dan aspek tampilan yang dinilai oleh dua orang ahli media adalah layak. Kelayakan produk dinilai dari aspek pembelajaran, dan aspek isi/materi yang dinilai oleh dua orang ahli materi adalah layak. Kelayakan produk ditinjau dari aspek pembelajaran, aspek materi, dan aspek media yang dinilai oleh enam responden uji beta adalah sangat layak. Dengan demikian, maka dapat disimpulkan bahwa produk multimedia pembelajaran interaktif IPA materi mikroorganisme layak digunakan sebagai salah satu media pembelajaran IPA di SMP.

Adapun spesifikasi atau keunggulan produk yang dihasilkan adalah produk didesain agar siswa mampu menggunakannya secara mandiri, materi yang disajikan adalah materi Protista dan Monera, penyajian materi disusun dengan model tutorial yang dilengkapi dengan berbagai animasi, pada awal materi ditampilkan video tentang keadaan alam sekitar sehingga siswa tertarik dan berusaha untuk mengkontruksi kemampuan awal yang dimiliki, evaluasi disajikan tidak hanya dalam bentuk soal tetapi juga dalam bentuk game drag and drop, dan untuk dapat menggantikan pengalaman belajar lang-sung disajikan videovideo berbagai jenis mikroorganisme.

Produk multimedia pembelajaran interaktif yang dihasilkan terbukti dapat meningkatkan pemahaman siswa pada materi mikroorganisme. Hal ini ditinjau dari (a) Hasil uji postest yang telah dilakukan. Berdasarkan hasil uji postest diketahui bahwa $83 \%$ siswa mencapai hasil belajar lebih besar dari angka KKM (75), dengan ratarata capaian hasil belajarnya 80,5. (b) Hasil analisis uji statistik paired sample t-test dengan program SPSS 23 diketahui bahwa peningkatan pemahaman siswa dengan menggunakan produk multimedia pembelajaran interaktif IPA adalah signifikan $(0,000)$, sehingga dapat dikatakan bahwa multimedia pembelajaran interaktif ini terbukti dapat meningkatkan pemahaman siswa pada materi mikroorganisme.
Berdasarkan simpulan tersebut, penelitian ini memberikan saran sebagai berikut. Pertama, multimedia pembelajaran interaktif dapat digunakan sebagai salah satu sumber maupun media belajar bagi siswa, dan dapat disebarluaskan di SMP lainnya secara langsung ataupun secara elektronik melalui media internet yang diunduh, diduplikasi atau dikemas menggunakan $\mathrm{CD}$ bagi siapa saja yang membutuhkan. Penelitian dan pengembangan lebih lanjut hendaknya dapat memperhatikan kebutuhan siswa sehingga dapat membantu dan memberikan kontribusi besar dalam meningkatkan pemahaman konsep dan menghilangkan pemikiran siswa tentang mempelajari materi yang sulit, bersifat abstrak, serta tidak menarik. Pengembangan multimedia pembelajaran interaktif lebih lanjut dapat menambaahkan kelengkapan komponen yang belum tersedia seperti penambahan evaluasi dan game yang dapat meningkatkan hasil belajar afektif dan psikomotor siswa. Selain itu juga dapat dilakukan penambahan cakupan materi yang lebih luas, penambahan video yang berhubungan dengan materi, tampilan animasi yang lebih menarik sehingga tidak timbul kejenuhan saat menggunakan program. Pengembangan lebih lanjut juga dapat dilakukan dengan mengubah aplikasi software kedalam bentuk .apk agar bisa diinstal di HP android siswa sehingga siswa bisa belajar kapan dan dimana saja.

Kedua, melalui pengembangan ini diharapkan juga dapat dilakukan untuk melengkapi materi pembelajaran IPA SMP yang belum tertuang dalam multimedia pembelajaran interaktif ini. Oleh karena itu, diharapkan dapat menghasilkan media pembelajaran IPA untuk semua materi yang diajarkan di SMP, dan diharapkan pembelajaran IPA akan menjadi lebih menarik, berkualitas, dan menerapkan penggunaan teknologi dalam proses pembelajaran.

\section{Daftar Pustaka}

Alessi, S. M., \& Trollip, S. P. (2001). Multimedia for learning: methods and 
development (3rd ed.). Boston: Allyn and Bacon.

Arkün, S., \& Akkoyunlu, B. (2008). A study on the development process of a multimedia learning environment according to the ADDIE model and students' opinions of the multimedia learning environment, Number 17 (October, 2008), hal: 1-19. Interactive Educational Multimedia, 17, 1-19.

Daryanto. (2010). Media pembelajaran. Yogyakarta: Gava Media.

Ekici, G. (2010). Factors affecting biology lesseon motivation of high school students. In Procedia - Social and Behavioral Sciences (pp. 2137-2142).

Heinich, R., Molenda, M., Russel, J., \& Smaldino, S. (1996). Instructional media and technologies for learning.

Englewood Cliffs New Jersey:

Prentice-Hall, Inc, Asimon \& Scuster Company.

Jumasa, M. A., \& Surjono, H. D. (2016). Pengembangan multimedia pembelajaran Bahasa Inggris untuk pembelajaran teks recount di MTSN II Yogyakarta. Jurnal Inovasi Teknologi Pendidikan, 3(1), 25-39. Retrieved from https://journal.uny.ac.id/index.php/ jitp/article/view/8287

Leow, F. T., \& Neo, M. (2014). Interactive multimedia learning: innovating classroom education in a Malaysian University. The Turkish Online Journal of Educational Technology, 13(2), 99 110.

Marsana, E. (2013). Pengembangan media berbasis komputer untuk pembelajaran fisika di SMA. Yogyakarta: Program Pascasarjana UNY.

Meyer, R. E. (2009). Multimedia learning: prinip-prinsip dan aplikasi. Yogyakarta:
Pustaka Pelajar.

Newby, T. J., Stepich, D., Lehman, J., \& Russell, J. D. (2000). Instructional technology for teaching and learning. Upper Saddle River, New Jersey: Prentice-Hall, Inc, Perason Education.

Phillips, R. (1997). The developers handbook to interactive multimedia (a practical guide for educational applications). London: Kogan Page Limited.

Prawira, Sulasmi, D. (1989). Warna sebagai salah satu unsur seni dan desain. Jakarta: Depdikbud.

Rusdewanti, P. P., \& Gafur, A. (2014). Pengembangan media pembelajaran interaktif seni musik untuk siswa SMP. Jurnal Inovasi Teknologi Pendidikan, 1(2), 153 - 164. Retrieved from https://journal.uny.ac.id/index.php/ jitp/article/view/2526

Sadiman, A. S., Rahardjo, R., Haryono, A., \& Rahardjito. (2012). Media pendidikan. Jakarta: Rajawali Pers.

Samikwo, D. C. (2013). Factors which influence academic perfomance in biology in kenya: a perspective for global competitiveness. International Journal of Current Research, 5(12), 42964300 .

Tan, S. C., \& Wong, A. F. L. (2003). Teaching and learning with technology. Singapore: Prentice Hall.

Wahyuni, S., \& Djukri. (2015). Pengembangan media pembelajaran berbantuan komputer dan keefektifannya terhadap kemandirian belajar dan penguasaan konsep bryophyte. Jurnal Inovasi Teknologi Pendidikan, 3(1), 79-91. Retrieved from https://journal.uny.ac.id/index.php/ jitp/article/view/8262 